\title{
小規模公園の管理実態とその評価に関する考察
}

\section{A Consideration about Management Structure and Subject of Small Park}

\author{
塚田 伸也* 石澤 知子** 湯沢 昭 ${ }^{* * *}$ \\ Shinya TSUKADA Tomoko ISHIZAWA Akira YUZAWA
}

\begin{abstract}
As the roles of the urban parks, there are the relaxation of the urban environment problem, the symbiosis with the nature, and the promotion of the regional community. The facilities in the parks are required the sufficiently functions and the conditions that can feel easy for the users. For the reason, the appropriate maintenance is necessary with the improvement for the urban parks. In this study, the data were used for the management plan measures of the urban parks from the maintenance data of the parks by the administrative officers in Maebashi-city. From the data by the administrative officers, the maintenance management structure model was developed. The main conclusions are as follows; (1)By the result of a park patrol in evaluation structure, it became clear that the whole park management image in the present small park has grasped quantitatively.

(2) By Evaluation of the parts in institution structure, the improvement target of plan and a design were able to be clarified by the problem to the maintenance. Accumulated result of the patrol by the evaluation is thought possible by carrying out the monitoring of the situation to specify the potential subject which park management holds.
\end{abstract}

Keywords: Park management, Evaluation structure, Quantification theory II キーワード：公園管理, 評価構造, 数量化理論第 I類

\section{1.はじめに}

都市に扔ける緑とオープンスペースの拠点となる小規模公園 ${ }^{11}$ は，戦後より急速に整備が進められてきており，その数と量を増 してきた。平成 9 年度末の現況は全国で 74,344 箇所, $86,226 \mathrm{ha}$ であり，都市公園の全体面積の $30.29 \%$ を占めている 近年におけるヒートアイランド現象をはじめとした都市環境問題 の顕在化, 自然との共生意識の高まり, 高齢化の急速な進展や地 域コミュニティの振興を踏まえ，身近な緑とオープンスペースの 挑点である小規模な公園へ多様な機能が期待されている。一方, 都市公園は整備と共にいかに適切に維持管理され，有効に利用さ れるかが重要であり, 施設の持つ諸機能が十分に発揮され, 常に 利用者が安心できる快適な状態でなければならない。しかし，今 日において管理水準の低下や施設の老朽化に伴い，本来の利用が 阻害されるなど公園施設内におりる安全性や防犯等が社会問題上 なっている ${ }^{3)}$ 。このことから時代の新しいニーズにあった都市公 園の適正な管理運営が求められており, 公園の形態, 市民とのパー トナーシップに基づき, 住民の多様な要求に応じた糼率的かつ適 切な管理が望まれている。近年において公園管理についての調査 研究が都市計画, 造園学を中心に行われており, 特に小規模公園 の管理に限定すると住民のボランティアによる公園管理（以下， 公園愛護会と称す）に関する調查研究が行われている。金子ら4) は主要都市における公園愛護会の成立過程と発足状况について調 査して招り, 根来ら ${ }^{5)}$ は公園愛護会の活動内容と団体の性格につ いて分析している。児玉ら ${ }^{6)}$ は行政上公園愛護会にアンケートを 行い, 両者の維持管理における意識について調査しており，岩村 ら は神戸市を事例に活動を調查し，愛護会活動を促進するため の方策として計画策定時の住民参画に着目している。

今日における公園の管理運営の問題を捉えると大きく 2 つに分 類される。1つ目は除草や清掃, 植物の消毒や剪定, 施設工作物 の修繥や点検，占用などの法的管理を含む「施設管理」であり， ストックの増大と施設の老朽化や植物の生長を踏まえ, 適切な施 設管理を効率的かつ効果的に行い，快適な公園の安全性を如何に 確保するかという問題である。2つ目は，イベントの実施や公園
の利用価値の高揚，利用マナーの育成なよ゙日常の公園利用で生じ る「利用管理」であり，利用者のモラルに起因する施設の破損や 公園における犯罪などの顕在を踏まえて利用者が公園への愛着を 醸成し，公園を有効に活用できる環境づくりを如何に育成できる かという問題である。以上の 2 つの公園管理における問題を捉え て今後の管理運営の方向性を探る場合, 公園の設置者であると共 に管理者である行政による公園管理の実態と評価の特性を把握す ることあ重要であるが，従来研究ではあまり見られない。そこで, 本研究では小規模公園の管理運営について管理者である行政によ る実務レベルの視点から捉えて公園の施設管理の現状と問題点を 把握する。これにより，公園の施設管理の観点から今日における 公園管理の実態と課題について考察を行い, 今後の適切な小規模 公園の管理について施設管理を行うための評洒指標を作成するこ とを目的としている。

\section{2. 研究の方法}

本研究では, 公園の適正な施設管理における問題構造を明らか にすることを目的に，群馬県前橋市に開設されている都市公園を 事例に調查, 分析を行うものとする。始めに公園の整備状況之管 理について, 前橋市の都市公園台帳及び前橋市各会計決算書を用 いて現状把握を行い，今日における公園管理の問題点を整理する。 次に，各々の公園施設の状況を把握するため，管理のためのチェッ クリストを作成した後, 前橋市公園緑地課職員による公園施設の パトロールを実施する。そして，公園施設のパトロールで得られ た結果について，数量化理論第 II類を適用し定量的に分析するこ とにより公園の施設管理を行うための基礎資料とし，施設管理の 実態を施設別, 全体像から捉えて問題構造を検討する。さらに, 公園の施設管理を計画的かつ具体的に実施するための公園施設の 評価指標を作成ことにより，今後の適正な公園管理の実施目標を 明らかにする。

\section{3．前橋市における公團管理の現状 （1）公團の整備状況}

:前橋工科大学大学院工学研究科 ${ }^{*}$ 日進工测(株) ***前橋工科大学建設工学科 
表一 1 平成 12 年度末における前橋市の都市公園整備状況 ${ }^{8)}$

\begin{tabular}{|c|c|c|c|c|c|c|}
\hline \multirow{3}{*}{ 蛙地㹉別 } & \multicolumn{3}{|c|}{ 市街化区城 } & \multicolumn{3}{|c|}{ 被市部西区域 } \\
\hline & \multicolumn{2}{|c|}{ 整僧 量 } & \multirow[b]{2}{*}{$\mathrm{m}^{2} /$ 人 } & \multicolumn{2}{|c|}{ 整维量 } & \multirow[b]{2}{*}{$\mathrm{m} / \lambda$} \\
\hline & 简河数 & 面皘 & & 䉒所数 & 而稍 & \\
\hline \multirow{3}{*}{$\begin{array}{l}\text { 住区 } \\
\text { 基除. } \\
\text { 公圆 }\end{array}$} & 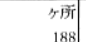 & $\begin{array}{r}\mathrm{hm} \\
39.54\end{array}$ & & 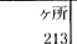 & $\begin{array}{r}\text { ha } \\
43.86\end{array}$ & 155 \\
\hline & 17 & $\begin{array}{l}39.54 \\
25.60\end{array}$ & - & $\begin{array}{r}213 \\
16\end{array}$ & $\begin{array}{l}43.86 \\
25,60\end{array}$ & $\begin{array}{r}1.555 \\
0.90\end{array}$ \\
\hline & 2 & 3.00 & 0.15 & 4 & 11.80 & 0.42 \\
\hline 榣合公洞 & 1 & 5.15 & 0.25 & 2. & 29.25 & 1.03 \\
\hline 速動公圆 & it & 36.60 & 1.80 & 4 & 89.30 & 3.16 \\
\hline 基锌公囷 & 209 & 109.89 & 5.39 & 239 & 199.81 & 7.06 \\
\hline \multirow{4}{*}{ 特殊公固 } & - & - & 0.00 & - & - & 0.00 \\
\hline & - & $-\cdots$ & 0.00 & - & - & 0.00 \\
\hline & i) & 0.25 & 0.01 & 1 & 0.25 & 0.01 \\
\hline & $=$ & $=$ & 0.00 & 1 & 55.30 & 1.95 \\
\hline ₹の他 & - & - & 0.00 & - & - & 0.00 \\
\hline 店棏公固 & - & - & 0.00 & - & - & 0.00 \\
\hline 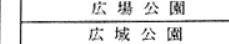 & - & - & 0.00 & - & - & 0.00 \\
\hline 䋁街緑地 & - & - & 0.00 & - & - & 0.00 \\
\hline \multirow{2}{*}{  } & 28 & 6.58 & 0.32 & 39 & 9.81 & 0.35 \\
\hline & 1 & 1.50 & 0.07 & 2 & 1.50 & 0.05 \\
\hline 钣 㭉 㷊 & - & - & 0.00 & - & - & 0.00 \\
\hline 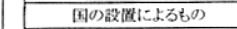 & - & - & 0.00 & - & - & 0.00 \\
\hline 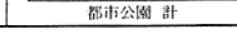 & 240 & 118.22 & 5.80 & 282 & 266.67 & 9.43 \\
\hline \multirow{2}{*}{ 人 口 } & \multicolumn{3}{|l|}{ 票街化区城 } & \multicolumn{3}{|c|}{203.768 人 } \\
\hline & 都市激画区 & & & \multicolumn{3}{|c|}{282,906 人 } \\
\hline \multirow{2}{*}{ 面i 稍 } & \multirow{2}{*}{\multicolumn{3}{|c|}{$\frac{\text { 市街化区城 }}{\text { 都市社画区域 }}$}} & & 4,6271 & \\
\hline & & & & \multicolumn{3}{|c|}{$14,735 \mathrm{ba}$} \\
\hline 全国䃌市公娄 & \multicolumn{3}{|c|}{ 人口 $1,172,727$ 千人 } & $903,000 \mathrm{t}$ & & 7.70 \\
\hline
\end{tabular}

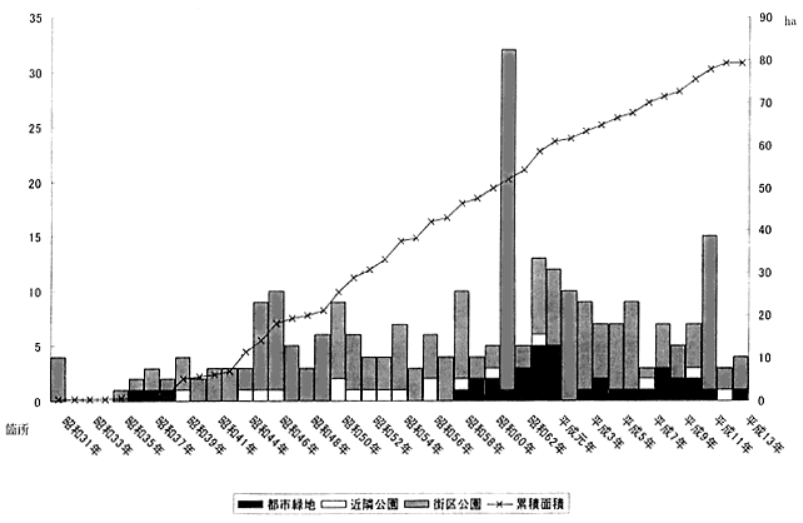

図－1 前橋市における年度別小規模公園整備量の推移

表一 1 は, 前橋市における平成 12 年度末の都市公園の整備状 況を示したものである。平成 12 年度末現在までに 282 箇所, 266.67ha の都市公園が整備されており, うち面積が比較的小さ な公園である都市緑地, 街区公園, 近隣公園 (以下, 小規模公園 と称す）は, 都市公園総数の $95.0 \%$, 面積割合が $29.7 \%$ 占め る。図- 1 は, 前橋市における年度別の小規模公園について整備 状況の推移を示したものである。眓より分かるように小規模公園 の整備は, 昭和 39 年度より急速 ${ }^{97}$ に整備が進められおり, 今日 まで整備後 20 年以上を経過している小規模公園が 113 箇所, 46.29ha 存在しており, 小規模公園総数の $58.4 \%$ 占めている。

前橋市の公園事業費 (公園費) は, 職員人件費, 都市基幹公園 整備事業費, 公園緑地整備事業費 (小規模公園の整備費), 公園 管理事業費, 都市緑化推進事業費の 5 つに大きく分類される。表一 2 は, 前橋市の公園費とその細目として職員人件費, 都市基幹公 園整備事業費, 公園緑地整備事業費, 公園管理事業費, 都市緑化 推進事業費，その他について年度別における会計決算額を前橋市 各会計決算書（昭和 63 年度〜平成 13 年度）により調查したもの である。この表より, 前橋市の公園費の合計は 11 億円から 25 億 円の範囲で推移しており, 公園管理事業費は年度ごとに増加傾向 にあることが分かる。平成 2 年度において公園費の $16.7 \%$ を占 めていた公園管理事業費は, 平成 7 年度に公園費の $34.1 \%$ に至 り, 平成 13 年度には $42.8 \%$ を占めることから公園管理費の急激 表－２＼cjkstart公園の総事業費亡事業内訳の推移

\begin{tabular}{|c|c|c|c|c|c|c|c|}
\hline \multirow{2}{*}{ 年湾 } & \multirow[b]{2}{*}{ 公围費 } & \multirow[b]{2}{*}{  } & & & & & \multirow[b]{2}{*}{ ₹の他 } \\
\hline & & & 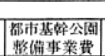 & 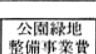 & 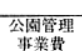 & 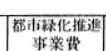 & \\
\hline 昭和63年度 & $2,574,765$ & 205,844 & $1,891,523$ & 109,031 & 237,38 & 117,215 & 13,768 \\
\hline 平成元年度 & $1,754,982$ & 217,482 & 902,796 & 157,985 & 333,556 & 131,413 & 11,750 \\
\hline 平成2年度 & $2,091,597$ & 236,632 & $1,137,360$ & 183,769 & 348,867 & 173,216 & 11,753 \\
\hline 平成3 年度 & $1,620,711$ & 253,326 & 510,394 & 339,521 & 380,568 & 125,537 & 11,365 \\
\hline 平成 4 年度 & $1,278,778$ & 269,845 & 303,996 & 124,441 & 394,807 & 173,363 & 12,326 \\
\hline 平成5年度 & $1,176,245$ & 287.088 & 247,176 & 89,909 & 385,574 & 141,884 & 24,614 \\
\hline 平成6年度 & $1,257,814$ & 302,097 & 272,878 & 111,437 & 415,152 & 135,503 & 20,747 \\
\hline 平成7年度 & $1,325,604$ & 312,304 & 285,268 & 100,432 & 452,335 & 154,861 & 20,404 \\
\hline 平成8年度 & $1,928,587$ & 325,286 & 735,712 & 101,705 & 525,318 & 209,351 & 31,215 \\
\hline 平成 9 年度 & $1,551,888$ & 307,007 & 481,600 & 92,446 & 488,216 & 153,088 & 29,531 \\
\hline 平成 10 年度 & $1,817,145$ & 298,806 & 454,195 & 102,345 & 797,564 & 134,210 & 30,025 \\
\hline 平成11年传 & $1,451,287$ & 287,136 & 365,088 & 96,941 & 525,083 & 142,658 & 34,381 \\
\hline 平成12年度 & $1,582,193$ & 300,789 & 245,200 & 268,606 & 613,557 & 137.574 & 16,467 \\
\hline 平成13年度 & $1,497,080$ & 269,444 & 207,800 & 209,464 & 640,368 & 155,815 & 14,189 \\
\hline
\end{tabular}

な増加傾向を䇲うことができる。また, 都市基幹公園整備事業費 の事業費が減少傾向にあり, 平成 2 年度において公園費の 54.4 \%を占めていた都市基幹公園整備事業費は，平成 7 年度に 21.5 $\%$ に至り, 平成 13 年度には $13.9 \%$ となっている。前橋市緑の基 本計画 ${ }^{10)}$ によると小規模公園の整備は, 今後屯平成 13 年度以降, 平成 27 年度までに $28.25 \mathrm{ha}$ （131 個所）の增加を見込んでおり, 施設の老朽化と施設量の増加を踏まえ, 施設の改修, 修縜を主と した施設管理費用の増大とそれに伴う都市基幹公園整備事業費等 の財源圧縮が想定されることから, 経済的で実効性の高い施設管 理の実施が必要である。

\section{（2）今日の公園の施設管理における問題点}

前橋市の施設管理は緊急性の高い屯のを除いて，「公園利用者 の直接的な意見あるいは公園愛護会からの要求, 行政職員による 公園パトロールの実施結果 (See)」によって, 「予算計画と次年 度の行動計画（Plan）」が作成され，この実施計画に基づき， 「対象公園の修繥や改修 (Do)」を行うという PDS サイクルによっ て実施される。しかし, 今日における公園の施設管理を行う際の 問題点の 1 つとして, 実施対象之なる公園が実施対象外の公園之 比較してどの位置付けにあるのか (全体像の把握), どのような 総合的対策を実施すべきか（問題構造の実態把握）が出来ていな いことが挙げられる。そこで, 今後の適切で効率性の高い公園の 施設管理を実現するためには, 従来の PDS サイクルから発展し, 「客観性が高い評価 (Check)」,「改善策の検討 (Action)」の充 実を図ったPDCA サイクルに基づく検討が必要であるといえる。

\section{4. 小規模公園の管理実態}

\section{(1) 公園パトロールの実施}

筆者が所属する前橋市公園緑地課では, 都市公園の管理状況を 把握するため, 公園緑地課職員による公園パトロールを市内の 281 箇所の都市公園を対象として表一 3 のとおり実施した。

表一 4 は, 調查時における評価対象とした施設を示したもので あり, 施設ごとに 4 段階で評価をしてもらった（評価 1 : 問題無 し, 評価 2 : 改善を検討すべきである, 評価 3 : 改善が必要で ある, 評価 4 : 至急改善が必要である)。調查は前橋市域を地区 に応じて, 調査公園数を 5 つに均等分割し, 在課経験 $3 \sim 20$ 年 の技術系職員 3 名, 技能系嬂員 1 名で編成される 1 班 4 人編成 （計 20 人）により行われ，評価は 4 人の評価の最頻值を採用した。 評価の基準は公園利用の安全性を特に重要な価值として植物, 構 造物，公園利用上から捉えて表－ 5 に示すような評価基準を設定 した。なお，公園内における複数の同施設の評価值は最低值とし， 「総合評価」は調查対象とした複数公園の施設評価の状況を踏ま えて客観的かつ総合的に評価してもらった。

また，表に示す入口とは，高齢者や障害者等の利用を踏まえて， 車イス進入時の入口の状態や障害の有無等を示したものである。 
表ー3 公圈パトロールの実施概要

\begin{tabular}{|c|c|}
\hline 調查日時 & 平成14年9月 \\
\hline 実施主体 & 前橋市公園䜌地課 \\
\hline 調查対象公園 & 前橋市に設置されてている281筒所の都市公園 \\
\hline 略查方法 & 公園緑地課職貝による現地趽查，調查書記入 (5瑟: 4人編成) \\
\hline
\end{tabular}

\section{表 -4 調查の対象施設}

\begin{tabular}{|c|c|c|c|c|}
\hline 植物 & 避践施般 & 休黄施毁 & 便益施設 & 管理施設 \\
\hline \multirow{2}{*}{ 芝生＊ } & ブランコ* & \multirow{2}{*}{ あづまや゙ } & \multirow{2}{*}{ 時計台 } & 栖躘 \\
\hline & 寸べり台米 & & & \\
\hline \multirow[b]{2}{*}{ 花弶 $*$} & 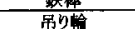 & \multirow[b]{2}{*}{ パージラ* } & \multirow[b]{2}{*}{ 水飲埸* } & 固名板 \\
\hline & 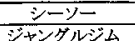 & & & 入口* \\
\hline \multirow{3}{*}{ 低木* } & $58-$ & \multirow{2}{*}{ ベンチ* } & \multirow{2}{*}{ 足洗場* } & 閒 \\
\hline & $\begin{array}{c}\text { 砂場* } \\
\text { アスン游具 }\end{array}$ & & & \\
\hline & ターザンローブ & \multirow{3}{*}{ 野外卓 } & \multirow{3}{*}{ 便所＊ } & 梅* \\
\hline \multirow{2}{*}{ 生垣* } & 造形游具 & & & 照明施設 * \\
\hline & 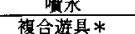 & & & 㩲壁 \\
\hline
\end{tabular}

表 -5 調查の評価基準

\begin{tabular}{|c|c|}
\hline & 評価2(改善検討) \\
\hline$\square$ & 軽微な損伹がみられる \\
\hline $\bar{\square}$ & 樹木が近い将来に利用安全，隣地に影響が想定される \\
\hline$\square$ & 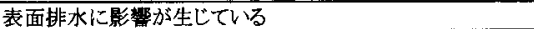 \\
\hline$\square$ & 染装の薄利等がみられる \\
\hline[ & 配置に問題あり \\
\hline$\square$ & 落書きがされている \\
\hline$\square$ & 部分的に劣化が見られる(近く修縉が要) \\
\hline$\square$ & ペットの粪, ヨ゙ミが散乱している \\
\hline $\bar{\square}$ & 東椅子の標淮幅 $(120 \mathrm{~cm})$ が確保されていない \\
\hline & 進入時勾配がきつい(基淮勾配饰以上) \\
\hline & 評価3 (要改善) \\
\hline$\square$ & 樹木が隣地に影響を与えている \\
\hline $\bar{\square}$ & 樹木，構造物の視界碓保に問題あり \\
\hline $\bar{\square}$ & 不陸が多数，生じている(機能に支障有) \\
\hline$\square$ & 構造物が部分的に損傷している(機能に支障有) \\
\hline$\square$ & 利用危険度が高い遊具がある \\
\hline$\square$ & 各施設の基礎が露出している \\
\hline$\square$ & 給，排水機能に影響が生じている（機能に支障有） \\
\hline$\square$ & 施設，施毅の1部が盜難されている(機能に支障有) \\
\hline$\square$ & 施設，施設の1部が破䧇されている(機能に支障有） \\
\hline [ & 車椅子で進入に支障となる段差, 障害物がある \\
\hline & 評価4(至急改善) \\
\hline$\square$ & 樹木や施設交通安全に問題あり \\
\hline 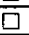 & 㰾木が枯損している \\
\hline$\square$ & 樹木や施設が防犯上問題かり \\
\hline$\square$ & 不陸が多数, 生じている(利用安全に支障有) \\
\hline $\bar{\square}$ & 排水構造物が全く機能していない \\
\hline $\bar{\square}$ & 棈造物が部分的あるい忙全損している(安全利用に支障有) \\
\hline$\square$ & 給，排水機能に影響が生じている(利用安全に支障有) \\
\hline$\square$ & 施設,施設の1部が盜難されている(利用安全に支障有) \\
\hline $\bar{\square}$ & 施設，施設の1部が破壊されている(利用安全に支障有) \\
\hline$\square$ & 車椅子の自走幅(最低 $90 \mathrm{~cm}$ )が確保されていない \\
\hline
\end{tabular}

表ー6はパトロールの実施結果に基づく代表的な評価項目の評 価值（該当なしを除く）を示したものである。総合評価において 4 之評価されたものは 15 箇所（ $5 \% ％ ， 3$ 之評価されたものは 118 箇所 (42.0\%)，2 2 評価されたものは 68 箇所 $(24.2 \%)$ で あり全体の $71.5 \%$ が改善もしくは改善の検討が必要であると評 価された。評価項目別の值を見ると, 植物では高木に対する改善 要求が高く, 該当公園 260 箇所の $46.5 \%$ が改善または改善検討 之評価された。問題点としては中央の広場空間を大きく確保する ために外周部に設けられた高木が経年による生長によって隣地, 電線への影響を与えていること，多層に設けられた樹木が園内の 見通しを妨げているなどが挙げられた。遊戯施設では砂場（該当 公園：168 箅所）が $54.8 \%$, 複合遊具（該当公園 104 箇所）が 43.3\%と改善または改善検討と評価された。問題点としては砂場 の砂の硬化や補充, 犬猫の䔬, コンクリートの劣化(例えば石の 山など）や木部の腐食（例えばアスレチック遊具）が挙げられた。 休養施設ではパーゴラ（該当公園：121 箇所）が $60.3 \%$, ベンチ （該当公園：249 箇所）が $46.2 \%$ と改善または改善検討之評価さ れた。問題点としては生長した藤を支えるパーゴラの垂木の劣化 や木製ベンチの木部の腐食が挙げられた。便益施設では便所（該
表一 6 代表的な施設の評価結果

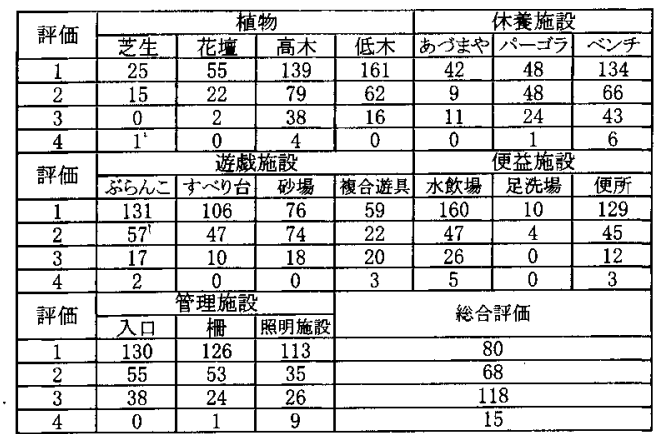

表一 7 数贯化理論第川類による分析結果

\begin{tabular}{|c|c|c|c|}
\hline 象 & 項 & レンジ & 偏相関保数 \\
\hline \multirow{5}{*}{$\begin{array}{l}\text { レベル 1-2 } \\
\text { 総合評価 }\end{array}$} & 植物総合 & 0.3818 & 0.1507 \\
\hline & 遊践施設総合 & 0.8294 & 0.3079 \\
\hline & 休堆施設総合 & 0.6421 & 0.2677 \\
\hline & 便益施設総合 & 0.5842 & 0.2315 \\
\hline & 管理施設総合 & 1.1167 & 0.4474 \\
\hline \multirow{5}{*}{$\begin{array}{c}\text { レベル 2-3 } \\
\text { 植物 }\end{array}$} & 芝生 & 0.4281 & 0.1181 \\
\hline & 花埴 & 1.0477 & 0.2241 \\
\hline & 高木 & 2.4305 & 0.8928 \\
\hline & 低木 & 0.4340 & 0.4056 \\
\hline & 生垣 & 0.6974 & 0.2087 \\
\hline \multirow{4}{*}{$\begin{array}{l}\text { レベル 2-3 } \\
\text { 遊戲施設 }\end{array}$} & ブランコ & 1.9192 & 0.5584 \\
\hline & すべり台 & 1.4237 & 0.3622 \\
\hline & 砂場 & 1.8062 & 0.5327 \\
\hline & 複合施設 & 1.3340 & 0.4632 \\
\hline \multirow{3}{*}{$\begin{array}{c}\text { レベル 2-3 } \\
\text { 休盖施設 }\end{array}$} & あづまや & 0.7636 & 0.3251 \\
\hline & パーゴラ & 1.4561 & 0.6714 \\
\hline & ペンチ & 2.0727 & 0.8295 \\
\hline \multirow{3}{*}{$\begin{array}{c}\text { レベル 2-3 } \\
\text { 便益施設 }\end{array}$} & 水飭場 & 2.5546 & 0.9245 \\
\hline & 足洗場 & 0.3736 & 0.1159 \\
\hline & 便所 & 2.0780 & 0.8152 \\
\hline \multirow{3}{*}{$\begin{array}{l}\text { レベル 2-3 } \\
\text { 管理施設 }\end{array}$} & 入口 & 1.6860 & 0.6685 \\
\hline & 榾 & 1.6745 & 0.6020 \\
\hline & 照明施設 & 1. 3694 & 0.5887 \\
\hline
\end{tabular}

当公園：189 箇所）が $31.7 \%$, 水飲栓（該当公園：238 箇所）が $32.8 \%$ ，管理施設では入口（該当公園：223 箇所）が $41.7 \%$ ，柵 （該当公園：190 箇所）が $41.1 \%$ に改善または改善検討と評価さ れた。問題点としては投石による照明灯の灯具の破損, 落書き, 立水栓の盗難, 身障者への対応が挙げられた。これらの結果から あ小規模公園の経年による植物の生長，施設劣化の深刻化を踏ま え, 利用マナーの育成も視野に入れた総合的な施設管理の奏施, 計画的な施設修繥と改修計画の立案が必要であることが分かる。

\section{(2)施設管理のための評価構造}

調查対象とした前橋市における公園の施設管理の状況を評価す

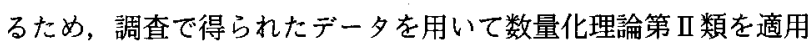
して分析を試みた。評価の作成にあたっては，レベル1を総合評 価, レベル 2 を施設の大分類, レベル 3 を各施設の内容として階 層的に配置した。パトロールで実施した 4 段階の評価を用い，レ ベル 2 の評価を目的变数, レベル 3 の管理評価を説明变数としだ。 但し, レベル 3 の評価は, サンプル数の問題から 3 段階評価 (1 : 問題なし，または該当なし，2：改善を検討， 3 : 改善が必要, または至急改善）とした。また，同様にレベル 2 の大分類の評価 を説明变数,レベル 1 の評価を目的変数として分析を行った。

表ー7は，分析で得られた結果を示したものである。表の結果 からレベル 1 とレベル 2 の関係では, 施設管理の総合評価に最も 影響を与えている項目はレンジの大きさより,「管理施設 (1.117)」,

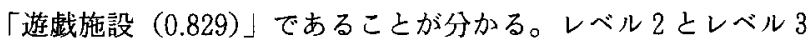
の関係では，「植物」について「高木（2.431)」が最も影響を与 えており，高木の生長に配虑した公園の計画や設計を行うことが 重要あり，生長を踏まえた適切な樹木管理の実施が重要と考えら れる。「遊齜施設」では,「ブランコ(1.919)」, 「砂場 (1.806)」, 「すべり台（1.424）」の順となっており，「休養施設」では「ベン チ(2.073)」,「パーゴラ (1.456)」の值が大きい。これらは, 従 


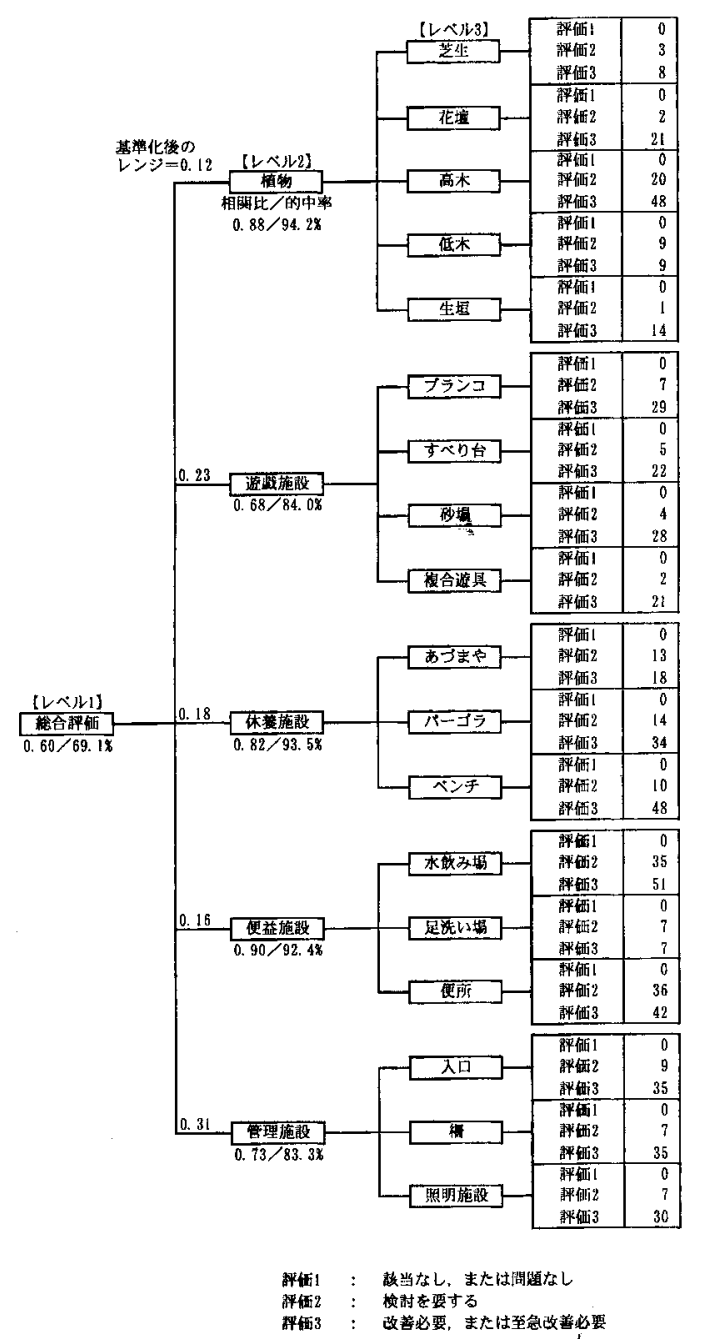

图ー 2 施設管理のための評価構造"

表 -8 施設管理の評価基準值

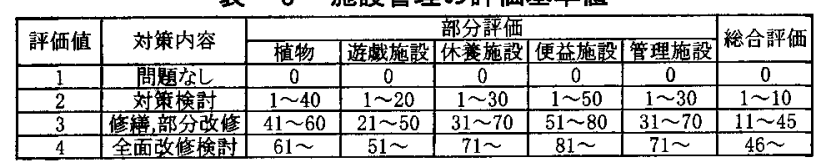

表 -9 評価構造の適用結果

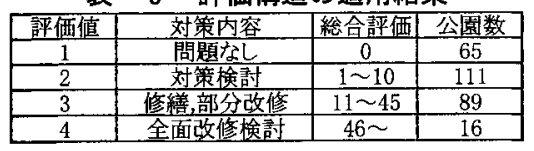

来から公園に設置された標準的な施設であり，定期的な塗装の実 施による施設の長寿化，老朽化した施設の改修検討が考元られる。 また，「便益施設」では「便所 (2.078)」, 「水飲栓 (2.555)」が, 「管理施設」では「入口 (1.686)」, 「栅 (1.675)」,「照明灯 (1.369)」の順となっている。

図一2は，表一 7 に示した分析結果から公園の施設管理のため の評価構造を表したものである。図中のレベル 3 の評価 1 から評 価 3 の值は，カテゴリウェイトの值を基準化したあのであり（レ ベル 2 毎に評価 3 の値の合計が 100 となるように，また評価 1 は 0 とし, 評価 2 はカデゴリウエイト值から比例配分し算出した), レベル 1 とレベル 2 間に掠ける基準化後のレンジの值は, 表 -7 に示したレンジの值（総合評侀）から算出したものである。例元 ば, レベル 2 の「植物」の下位に位置するレベル 3 の 5 つの評価
項目の評価が全て 3 の場合には, 総合評価の中の「植物」の数值 は $12(0.12 \times 100)$ となる。また, レベル 3 に示す全ての評価項 目の評価が 3 の場合に総合評価の値は 100 となる。表一 8 は, 図一 2 により算出された部分評価之総合評価の値から，公園の施設管 理を実施するための評価基淮值を示したものである。なお，部分 評価の基準值は数量化理論第 II 類による判別境界値を基準として 算出した。これらの図表を用いることにより, 公園の施設管理状 況を総合的かつ定量的に把握することが可能となる。表一 9 のと おり, 実際にこの評価方式を適用した結果, 計 16 箇所の公園が 評価 4 (全面改修の対象), 計 89 筒所の公園が評価 3 (修繥また は部分改修の必要性あり）との結果が示された。この結果からあ 地方都市における「施設管理」のための財源確保が今後, 重要な 位置を占めることが分かる。

\section{5. 結U}

適正な小規模公園の管理運営は, 管理者による計画的な施設管 理の実施と利用者である地域住民の利用マナーやモラルの向上に より，実現できるあのであると考える。本研究では，管理者によ る公園パトロールの実施とこれを分析し公園管理のための評洒指 標を作成することにより以下の所見について考察することができ る。

1）公園パトロールの実施と実施結果を評価構造にまとめること で，現在の小規模公園に㧍ける施設管理の全体像が定量的に把握 することができた。なお，住民へのアカウンタビリティの向上を 踏まえ，施設管理における個別公園の状況，施設管理を実施する 際の客観的公平性を示すことができた。

2) 施設別に評価を行うことで, 施設か内内在する施設管理の問題 点を特定することにより, 計画・設計時の物理的な実施手段の検 討と改善目標を明確化することができた。

3）評価指標によるパトロールの結果を蓄積し，その対応状況を モニタリングすることにより施設管理の状況変化の把握, 抱える 潜在的な課題を特定することも可能であると考元られる。さらに, 評価データ一を公園台帳等ヘリンク,システム化することにより, 適切で効率的な施設管理の実現に繫がるものと考える。

\section{補注及び引用文献}

1) 本研究では，面積要件から街区公園，近除公園，都市緑地を小規模公 園しして取り扱っている。

2)（社）日本公園緑地協会 (1998)：公園緑地マニュアル(改訂 10 年度版), pp. 121

3）小出治（2000）：公園づくりにおける防犯環境設計：公園緑地 60(6)， $13-15$

4）金子忠一・内山正雄 (1983)：都市公園の管理体制についての研究： 造園雑誌 45(6)，99-104

5）根来千秋・渡辺謙三（1987）：児童公園の管理における住民の参加・ 協力に関する研究：都市計画学会論文集 $22,271-276$

6 ）児玉陽子・䳋田善昭・船渡悦夫（1999）：公園愛護会による街区公園 の維持管理の害態について: 土木計画学研究・講演集 22(1), 255-258

7 ）岩村高治・横張真（2002）：公園計画策定時における住民参加がその 後の公園管理運営活動に与える影響：ランドスケープ研究 65(5), $735-738$

8 ）前橋市の都市計画区域は行政区域全体を網維している。

9 ）前橋市では昭和 60 年度以前まで都市計画公園に限定し開設を行って きたが，昭和 61 年度以降は都市化の進展を踏まえ，従前から段階的 に整備された小規模開発等で設置された公園も都市公園として開設す ることとなる。図に示す昭和 61 年度の公園数の堌加はこれらの小公 園（300 $\mathrm{m}^{2}$ 末満のむの） 31 筒所を都市公園（種別：児童公園）として 位置付け開設された結果である。

10）前橋市（1998）：前橋市緑の基本計画

11）レベル 2 及びレベル $3 に$ 示す相関比／的中率は数量化理論第 I 類の適 用による判別精度を表す統計值である。 